\title{
Jaringan Lintas Komunitas Menuju Pembangunan Partisipatif Berkelanjutan
}

\author{
Muhammad Nelza Mulki lqbal \\ Prodi Arsitektur, Fak. Teknik Sipil dan Perencanaan, ITN Malang \\ e-mail: nelzamiqbal@lecturer.itn.ac.id \\ Putri Herlia Pramitasari \\ Prodi Arsitektur, Fak. Teknik Sipil dan Perencanaan, ITN Malang \\ e-mail:putri_herlia@lecturer.itn.ac.id
}

\begin{abstract}
ABSTRAK
Pembangunan partisipatif di Indonesia untuk mengatasi masalah-masalah kota terutama terkait dengan penanganan permukiman kumuh dan pengentasan kemiskinan semakin digalakkan terutama sejak era desentralisasi dimulai. Desentralisasi sejatinya menawarkan komitmen pemerintah pusat dalam mendelegasikan tanggung jawab pada pemerintah daerah untuk memantik kerjasama multi sektor dan partisipasi masyarakat. Sayangnya, banyak program pemerintah yang melibatkan partisipasi masyarakat di masa awal desentralisasi menemui jalan buntu terutama terkait keberlanjutannya. Kampung Improvement Program (KIP) pada era 1970-1980 menjadi salah satu contoh yang menarik untuk dikaji kembali dengan memberikan perbandingan pada inisiasi pembangunan lingkungan berbasis masyarakat terkini seperti yang dilakukan Arkom (Arsitektur Komunitas) Yogya dan Paguyuban Kalijawi di Yogyakarta.
\end{abstract}

Paper ini tidak akan mengulangi pembahasan pembangunan partisipatif terkait dengan tingkat kepentingannya, bentuk dan tantangan mengapa hal ini perlu dipertahankan. Namun, memberikan fokus terkait bagaimana menemu-kenali dan menggalakkan inisiasi-inisiasi perbaikan lingkungan berbasis masyarakat pada konteks negara demokratis dan meiliki aspek sosial-budaya yang kental seperti Indonesia. Penelitian pada paper ini merupakan penelitian kualitatif dengan deskripsi analisis melalui pengumpulan data berbasis literatur dan observasi lapangan untuk memberikan gambaran pokok permasalahan yang ada. Hasil komparasi kedua proyek diatas menunjukkan bagaimana peran jaringan lintas komunitas mampu memberikan dampak signifikan dalam mewujudkan pembangunan partisipatif berkelanjutan di Indonesia.

Kata kunci : Komunitas, Partisipatif, Jaringan, Berkelanjutan 


\begin{abstract}
Participatory development in Indonesia to address urban enviromental problems, especially those related to slum settlement and poverty alleviation, has been increasingly encouraged, especially since the era of decentralization began. Decentralization actually offers a commitment from the central government in delegating responsibility to local governments to stimulate multi-sector cooperation and community participation. Unfortunately, many government programs that involved community participation in the early stage of decentralization were stacked, especially regarding their sustainability. The Kampung Improvement Program (KIP) in the 1970-1980 era is an interesting example to be reviewed by providing a comparison of the latest community-based environmental development initiatives such as those carried out by Arkom (Community Architecture) Yogya and the Kalijawi Community in Yogyakarta.
\end{abstract}

This paper will not repeat the discussion aroud participatory development in terms of its importance, form and challenges why it needs to be maintained. However, it focuses on how to identify and promote community-based environmental improvement initiatives in the context of a democratic country and socio-cultural climate like Indonesia. The research in this paper is a qualitative research with a descriptive analysis through literature-based data collection and field observations to provide an overview of the main problems that exist. The results of the comparison of the two projects mentioned above show how the role of cross-community networks can have a significant impact in realizing sustainable participatory development in Indonesia.

Keywords: Community, Partisipatory, Networks, Sustainable

\title{
1. PENDAHULUAN
}

Desentralisasi di Indonesia mulai diberlakukan pada Januari 2001 sebagai bentuk komitmen negara kepada pemerintah daerah dan pembangunan berkelanjutan (Sumarto, 2008). Dengan adanya desentralisasi maka akan terjadi pelimpahan pendelegasian tanggung jawab dari pemerintah pusat kepada pemerintah daerah yang dimaksudkan untuk lebih menggalakkan partisipasi masyarakat, keterlibatan warga, dan kerjasama lintas aktor dalam mengatasi masalah-masalah di daerah. Perubahan ini tentunya menjadi pertanda bahwa masyarakat adalah fokus utama dalam pengambilan keputusan perencanaan dan kebijakan pembangunan. Hal ini sejalan pula dengan Agenda Tujuan Pembangunan Berkelanjutan (SDGs) 2030 dan Habitat III terkait keterlibatan dan masyarakat dalam mewujudkan ketahanan komunitas (Ley, 2018). 
Seperti halnya pada banyak budaya di negara-negara Asia, Indonesia juga merupakan negara yang masyarakatnya secara spasial dan sosial hidup bersama dalam bentuk komunitas yang terbiasa terhubung dengan jaringan-jaringan kelompok (ACHR, 2010). Masyarakat mengorganisir dirinya dalam bentuk kelompok dan komunitas untuk memecahkan masalah bersama. Kelompok berbasis komunitas ini bermaksud untuk mencari solusi bersama atas permasalahan yang sedang dihadapi juga meningkatkan kapabilitas dan kemampuan mereka secara berkelompok. Seringkali bentuk komunitas ini hadir diluar jaringan formal yang diinisiasi oleh negara seperti halnya Rukun Tetangga atau Rukun Warga sehingga keberadaanya menjadi lebih fleksibel dalam menjalankan tujuan bersama namun disaat yang sama juga rentan terhadap permasalahan modal dan jaringan yang lebih luas.

Desentralisasi telah membuka ruang sebanyak-banyaknya ruang partisipasi warga dan masyarakat dalam turut andil memberikan solusi permalahan lingkungan. Paper ini tidak akan mengulangi pembahasan pembangunan partisipatif terkait dengan tingkat kepentingannya, bentuk dan tantangan mengapa hal ini perlu dipertahankan. Namun, memberikan fokus terkait bagaimana menemu-kenali dan menggalakkan inisiasi-inisiasi perbaikan lingkungan berbasis masyarakat pada konteks negara demokratis dan meiliki aspek sosial-budaya yang kental seperti Indonesia. Ada dua fokus studi yang coba dipaparkan yakni inisiasi pemerintah dalam mewujudkan pembangunan partisipatif melalui Kampung Improvement Program dan inisiasi mandiri masyarakat marjinal kota pada praktek kerja Paguyuban Kalijawi di Yogyakarta.

\section{TINJAUAN PUSTAKA}

\subsection{Partisipasi Komunitas di Masa Awal Desentralisasi}

Kendati secara formal dimulai pada awal tahun 2001, keran desentralisasi dan partisipasi masyarakat sebenarnya mulai terbuka sejak 1998 bahkan lebih jauh pada medio 1970-1980 disaat merebaknya strategi ekonomi liberal dengan jargon 'trickle down' nya (Mayo 1995, Purba, 2011). Pada ranah pembangunan permukiman dan pengentasan kemiskinan serangkaian inisiasi pemerintah juga disokong oleh beberapa lembaga donor seperti Bank Dunia dan IMF. Kedua donor ini beragumen bahwa negara sejatinya harus berfokus pada penyediaan infrastruktur dasar dan mendorong partisipasi warga dan komunitas. Saat ini argumentasi ini masih cukup relevan dan menjadi dasar pengaplikasian inisiasi pemerintah terkait pembangunan partisipatif baik melalui mekanisme Musrenbang maupun Kecamatan Development Program (Sindre, 2012).

Pada masa awal perlibatan partisipasi masyarakat dan intervensi modal asing di Indonesia, Bank Dunia memberikan pemibiayaan pada serial 
proyek Kampung Improvement Project (KIP) pada medio 1970an yang dimulai di Jakarta. Pada saat itu intervensi KIP terkait perbaikan lingkungan dan pemberdayaan masyarakat masyarakat acapkali dianggap sukses dengan salah satu indikator nya adaah di raihnya penghargaan Internasional bergengsi Aga Khan Award for Architecture pada tahun 1980. Inisiasi KIP berfokus pada beberapa hal diantaranya perbaikan fisik lingkungan dan sosio ekonomi warga kampung, peningkatan kapasitas dalam melakukan produksi, dan pengurangan gangguan ekonomi dan sosial (Mintorogo, et.al 2015).

Semangat pemberdayaan masyarakat pada proyek KIP diindikasikan dengan perlibatan masyarakat pada proses konstruksi, relokasi, dan perawatan arae publik. Melalui perbaikan fasilitas dan infrastruktur dasar KIP membuatnya mampu menjadi pemantik gerakan perbaikan lingkungan di banyak kota di Indonesia seperti Surabaya, Yogyakarta, Makasar, Bandung Semarang dan bahkan menjadi panutan program perbaikan permukiman kumuh pada skala regional Asia. Pada banya penelitian terdahulu KIP acapkali dianggap sebagai pioner dan salah satu praktek perbaikan permukiman kumuh yang dianggap paling berhasil.

Kendati demikian KIP juga tidak lepas dari banyak kritik terutama terkait dengan tingkat partisipasi, jangkauan program, dan keberlanjutannya. Meskipun diklaim mampu menjangkau hingga 60\% populasi masyarakat untuk berpartisipasi namun partisipasi pada KIP masih berkutat pada pemberian informasi dan konsultasi belaka (ACHR, 2010). Sehingga peran masyarakat masih berkutat pada ranah pengaplikasian proyek saja. Acapkali juga ditemukan program yang sebenarnya tidak tepat untuk dijalankan karena sudah dilaksanakan atau sedang berjalan namun seakan 'dipaksa' untuk menjalankan KIP. Hal ini juga mengindikasikan kelemahan jangkauan program KIP yang dikarenakan program ini masih kental unsur "top-down approach" sehingga banyak ditemui kendala dan ketidak tepatan intervensi di lapangan.

KIP juga hanya menyasar wilayah-wilayah permukiman legal sehingga intervensi wilayah-wilayah kumuh yang tidak memiliki status kepemilikan yang jelas tidak akan bisa di jangkau oleh program ini (Das, 2009). Dengan fakta ini, sangat mungkin KIP menjadi tidak relevan pada konteks Indonesia. Karena secara historis kebanyakan kampung di Indonesia berada di area ilegal yang bersinggungan dengan isu-isu legalitas seperti kampung di area sepanjang rel kereta api maupun di sepanjang aliran sungai. Sehingga KIP pun menimbulkan banyak pertanyaan terkait konsep pembangunan bottomup, yang lantas berkembang menjadi keraguan untuk menganggap KI sebagai salah satu bentuk realisasi desentralisasi yang mampu menempatkan masyarakat sebagai subyek dari pembangunan. 
Terkait dengan keberlanjutan setidaknya terdapat dua hal yang perlu diketahui, bahwasanya KIP berfokus pada penyediaan infrastruktur dasar diantaranya perbakan jalan, drainase, toilet umum, dan penyediaan air bersih. Namun, program-program KIP tidak ada yang bersinggungan dengan isu-isu lingkungan seperti penghijauan, pengelolaan sampah maupun energi (Mintorogo, 2015). Kelemahan aspek keberlanjutan kedua adalah terkait dengan pengelolaan dan perawatan. Meskipun berhasi menjangkau banyak wilayah, namun dengan keterlibatan yang rendah maka kecenderungan proyek-proyek pasca KIP menjadi tidak terawat. Kita ambil saja contoh proyek-proyek KIP di Jakarta sebagai kota pertama tempat intervensi proyek-proyek KIP dimana sangat sulit untuk menemui peninggalan proyek-proyek KIP di Jakarta saat ini. Meskipun terdapat faktor perubahan tata guna lahan dan akselerasi pembangunan namun jika dilihat hanya dalam jangka waktu 5-10 tahun proyek-proyeke KIP sudah cukup sulit untuk ditemui. Jakarta juga mengalami perubahan besar-besaran terkait dengan komersialisasi wilayah pada medio 1980-an sehingga menyebabkan banyak kampung bergeser peruntukannya (ACHR, 2010).

Kurangnya perawatan akibat tidak adanya biaya dari pemerintah daerah maupun masyarakat di area proyek KIP menjadi faktor kunci mengapa KIP tidak bisa berjalan berkelanjutan. Komitmen yang singkat antara masyarakat dikarenakan metode partisipasi yang sangat dasar juga memberikan pengaruh signifikan mengapa KIP tidak mampu untuk bertahan. Kebanyakan proyek KIP akan selesai pada periode satu tahun, sehingga dapat dikatakan partisipasi masyarakat pada KIP sangatlah rendah (Das A. , 2015).

\subsection{Konsep Komunitas dalam Pembangunan Partisipatif Berkelanjutan}

Memahami konsep komunitas dalam pembangunan partisipatif berkelanjutan tidak hanya relevan namun menjadi sesuatu yang penting untuk dipahami. Kegagalan KIP didalam keberlanjutan proyek dan perawatan ditengarai juga dikarenakan kegagalan memahami peran serta komunitas dalam pembangunan. Butcher lalu mengidentifikasi tiga prinsip yang saling terkait untuk memahami komunitas yakni, penggambaran komunitas, komunitas sebagai nilai, dan komunitas (Butcher, 1993). Penggambaran komunitas akan terkait dengan bagaimana awalnya komunitas ini terbentuk dan bisa sangat bervariasi dari hanya sekedar alasan geografis sampai dengan ketertarikan terhadap hal yang serupa. Proses memahami bagaimana komunitas ini terbentuk dari sejarahnya, aktor yang terlibat, dan juga tujuan mereka berkomunitas akan sangat berguna dalam membangun karakter pembangunan yang sesuai dengan identitas mereka didalam pendekatan partisipatif. 
Komunitas sebagai nilai dikorelasikan dengan rasa ketergantungan terhadap ikatan komunitas yang dapat memperkuat nilai-nilai kebersamaan seperti halnya solidaritas, kesatuan dan partisipasi. Hal tersebut didapatkan dari tingkat loyalitas yang dibangun melalui kerjasama yang saling menguntungkan, kontribusi dari tiap individu, serta rasa pertalian yang kuat untuk mewujudkan tujuan bersama.

Prinsip terakhir dalam memahami komunitas terletak pada komunitas yang aktif, hal ini berkaitang dengan perasaan memiliki dan ketergantungan diantara komunitas dimana masyarakat didalam komunitas akan secara aktif terlibat membangun masa depannya dalam keseharian mereka. Ini menunjukkan satu kenyataan pasti bahwa kita membutuhkan sesuatu yang berulang dalam proses menjaga dan menumbuhkan nilai kebersamaan. Komunitas yang aktif bertumpu pada tingkat partisipasi anggota komunitas, kelompok, dan organisasi dalam memperkuat kehidupan berkomunitasnya (Day, 2002).

Komunitas yang aktif tidak hanya menghubungkan dirinya pada mekanisme dan koneksi horizontal tetapi juga memperluas relasinya kepada hubungan vertical untuk mendapatkan perubahan yang mendasar. Pada era modern seperti saat ini, tidak cukup kita bekerja hanya mengandalkan kemampuan mandiri individu maupun kelompok dan lantas mengabaikan adanya relasi kuasa vertical yang nyatanya memang ada. Komunitas yang aktif dapat memperkuat aspek demokratis dengan merubah sikap menerima dan pasif masyarakat menuju sebuah kepercayadiri-an dalam usahanya merubah keadaan-keadaan yang tidak tepat.

Bukti nyata dari adanya komunitas yang aktif dapat dilihat melalui tumbuhnya inisiatif-inisitaif baru di kota-kota Asia melalui perbaikan permukiman informal yang didasarkan oleh kebutuhan komunitas melalui gerakan-gerakan berbasis kelompok (Fitrianto, 2014). Perbaikan permukiman informal perkotaan seringkali dikatikan dengan perbaikan kawasan kumuh. Berbeda dengan banyak proyek pembangunan besar yang terjadi di Asia sebelumnya, inisiatif -inisitif ini terkoneksi satu dengan lainnya melalui jaringan yang lebih luas dan melibatkan tidak hanya berbagai komunitas, aktifis, akademisi, dan juga professional.

Penyertaan jaringan-jaringan yang lebih luas dan juga berbagai institusi menjadi penting dalam proses partisipatif untuk mendapatkan dukungan, pertukaran pengetahuan, dan membangun persekutuan [alliances]. Contoh yang terjadi dapat diambil dari jaringan ACCA (Asian Coalition for Community Action) juga SDI (Slum Dwellers International yang beropasi menangani permasalah negara-negara global south (Mitlin \& Satterthwaite, et.al 2012). Kedua organisasi tesebut berisikan professional, NGO's, dan komunitas-komunitas yang berkomitmen untuk mencari perubahan di negara dimana mereka berada. Selain dapat memperkuat 
modal sosial, jaringan yang luas dengan melibatkan banyak pihak dan institusi akan membantu mendapatkan solusi yang lebih luas dalam hal pemberdayaan dan juga pembangunan berkelanjutan.

\section{METODE PENELITIAN}

Penelitian dilakukan secara kualitatif dengan deskripsi analisis untuk menghasilkan kedalaman kajian penelitian. Deskripsi analisis dilakukan dengan melakukan tabulasi data berdasarkan fokus penelitian untuk kemudian dilakukan pengolahan dan analisis sehingga mampu memberikan gambaran mengenai permasalahan yang ada (Sugiyono, 2017). Adapun teknik tabulasi pengumpulan data dilakukan melalui telaah literatur terkait dengan judul yang didapat melalui berbagai sumber seperti buku, jurnal, berita baik online maupun offline.

Data yang terkumpul kemudian diintrepertaskan dengan studi kasus yang diambil terkait dengan inisiasi pemerintah dan masyarakat dalam mewujudkan pembangunan partisipatif. Selain deskripsi analisis, proses olah data juga disertai analiasa sejarah praktek awal pembangunan partisipatif sehingga dihasilkan indentifikasi mendalam dari praktek yang telah ada sebelumnya. Selanjutnya informasi deskriptif dan studi empiris digunakan untuk memberikan validitas pada penelitian kualitatif.

\section{HASIL DAN PEMBAHASAN}

Desentralisasi dimulai sejak tahun 2000 dan dianggap sebagai tonggak berakhirnya rezim perencanaan terpusat yang telah berjalan lebih kurang tiga dekade lamanya. Idealnya, desentralisasi mampu menjadi jalan setiap wilayah di Indonesia baik pada skala kota maupun provinsi untuk lebih memiliki otonomi terhadap wilayahnya masing-masing (Nasution, 2016). Dengan demikian harusnya desentralisasi mampu meningkatkan relasi antara masyarakat dan pemerintah. Aktivasi peran pemerintah daerah dapat membuka banyak peluang kolaborasi dan kerjasama inklusif pada ranah-ranah sosial, budaya dan ekonomi. Sayangnya desentralisasi masih dianggap belum mampu memecahkan permasalahan terkait kesetaraan dan keadilan terutama permasalahan perbaikan lingkungan.

Sementara itu sejalan dengan semangat reformasi, semakin banyak komunitas dan kelompok masyarakat yang bergerak mengaktifasi pendekatan bottom-up dalam mewujudkan perbaikan dan pembangunan lingkungan yang lebih baik. Hal ini juga sejalan dengan modal sosial serta kecenderungan masyarakat Indonesia untuk saling membantu satu dengan lainnya dalam bingkai gotong royong. Budaya kolektif gotong royong didasarkan semangat kebersamaan berbasis saling berbagi dan tolong menolong. Konsep ini mengakar dalam kehidupan sehari-hari masyarakat 
indonesia yang terbiasa menjalin relasi persaudaraan, pertemanan, dan bermasyarakat. Gotong royong merujuk pada kontribusi setiap individu terhadap kepentingan bersama dengan dasar segala permasalahan akan dapat diselesaikan dengan baik apabila di lakukan secara bersama-sama (lqbal, 2018). Gotong royong merupakan modal yang sangat baik untuk memulai proses pembangunan partisipatif yang berkelanjutan mengingat gotong royong bisa di gaungkan baik melalui mekanisme institusional formal maupun kebanyakan berada pada ranah-ranah informal.

Salah satu pergerakan yang menunjukkan indikasi adanya pergerakan komunitas aktif dengan semangat kebersamaan goong rayang muncul di Yogyakarta. Pada 21 April 2014 ratusan warga yang tinggal di bantaran sungai Winongo datang di Pendopo Yogyakarta didampingi ARKOM (Arsitektur Komunitas) Yogyakarta untuk bertemu dengan pemerintah daerah dan menuntut adanya perencanaan berbasis komunitas di kawasan lingkungannya (Widiyanto, 2014). Hal yang menarik dari inisiasi ini adalah komunitas yang menamakan diri sebagai Paguyuban Kalijawi tidak hanya memberi penjelasan mengapa mereka harus terlibat dalam proses perencanaan dan pembangunan tetapi menunjukkan hasil perencanaan yang telah dilaksakan sebelumnya. Selain menunjukkan perencanaan perbaikan lingkungan melalui metode pemetaan (mapping) juga ditunjukkan pula tabungan komunitas yang dikumpulkan secara berkala sebagai modal perbaikan lingkungan bersama.

Hal ini merefleksikan cara pandang berbeda dalam memahami ruang dan sangat terkait dengan bagaimana ruang diproduksi seperti teori yang dikemukaan Henri Lefebvre sebagai perceived space, conceived space, dan lived space (Setiawan, 2017). Masyarakat dan komunitas yang tinggal di area bantaran sungai melihat ruang di area sungai sebagai sebuai kesempatan yang berkembang dari tempat bermukim, berinteraksi, dan tempat yang bernilai secara ekonomi (perceived space). Kemudian cara komunitas untuk memproyeksi perencanaan perbaikan lingkungan dimasadepan melalui jalan pemetaan merupakan bagian dari praktek conceived space, dimana masyarakat mampu menunjukkan eksistensinya dan memproduksi pengetahuan pada lingkungan yang ditinggali. Sedang praktek lived space merupakan proyeksi abstrak pengalaman hidup yang akhirnya memberikan kekuatan dan alasan masyarakat untuk bertahan hidup di lingkungan tersebut.

Kembali ke diskusi inisiasi pemerintah melalui proyek-proyek KIP maka jika kita memberikan perbandingan dnegan inisiasi komunitas dan masyarakat maka kita akan melihat bentuk partisipasi yang berbeda. Pada era awal desentralisasi sangat terlihat jelas bagaimana limitasi partisipatif yang diawali pendekatan top-down terutama terkait aspek keberlanjutannya. Sementara inisiasi komunitas lokal seperti yang terjadi di Yogyakarta terlihat bagaimana komunitas bisa mengorganisir kelompok, membuat perencanaan, memetakan, dan memutuskan arah gerak mereka di masa 
depan. Hal ini terjadi karena keinginan kuat komunitas untuk mempertahankan dan juga meningkatkan kualitas lingkungan hidupnya.

Proyek-proyek KIP di Indonesia bisa jadi dinilai sebagai salah satu proyek peningkatan kualitas kawasan kumuh yang berhasil dalam menstimulasi proyek partisipasi komunitas dan masyarakat. Namun kurangnya dukungan sosial dan ekonomi menjadikan proyek-proyek ini seakan mudah muncul namun mudah dilupakan. Padahal isu keberlanjutan proyek sangatlah krusial jika dikaitkan dengan tujuan pembangunan dan transformasi lingkungan jangka panjang. Sehingga perlu adanya pertimbangn aspek politis, ekonomi, dan sosial yang utuh dalam mewujudkan strategi partisipatif yang berkelanjutan (Mayo, et al 1995).

Seperti dibahas sebelumnya, gotong royong memegang peranan kuat sebagai keraifan lokal khas Indonesia untuk kemudian menjadi dasar program partisipatif komunitas. Inisiasi yang dilakukan Paguyuban Kalijawi di Yogyakarta pada dasarnya meneruskan tradisi kegotong royongan khas masyarakat Jawa dan juga cerita panjang tentang informalitas dan peningkatan kualitas permukiman terutama pada permukiman di sepanjang sungai. Contoh yang cukup baik adalah karya Romo Mangunwijaya pada program peningkatan kualitas kawasan kali code yang juga memenangkan penghargaan bergengsi Aga Khan Award for Architecture pada tahun 1992. Kampung Code sendiri masih eksis dan berkembang serta selalu menjadi rujukan pembangunan partisipatif komunitas dan masyarakat yang menginspirasi banyak inisiasi serupa di seluruh Indonesia.

Jika dibandingkan KIP dengan inisiasi Kalijawi berdasarkan pertimbangan aspek politis, ekonomi dan sosial maka akan dihasilkan tabel berbandingan sebagai berikut :

Tabel 1.

Perbandingan KIP dna Kalijawi

\begin{tabular}{|c|c|c|c|}
\hline Proyek & Politis & Ekonomi & Sosial \\
\hline $\begin{array}{l}\text { Kampung } \\
\text { Improvement Program }\end{array}$ & $\begin{array}{l}\text { - top down program } \\
\text { - pemerintah pusat } \\
\text { dengan pengawasan } \\
\text { pemerintah daerah }\end{array}$ & $\begin{array}{l}\text { - dana berasal dari } \\
\text { dana pinjaman bank } \\
\text { dunia } \\
\text { - } \\
\text { pengembalian oleh } \\
\text { pemerintah pusat }\end{array}$ & $\begin{array}{l}\text { - partisipasi rendah } \\
\text { hanya berkutat pada } \\
\text { aspek pelaksanaan }\end{array}$ \\
\hline $\begin{array}{l}\text { Paguyuban Kalijawi } \\
\text { dan Arkom Yogya }\end{array}$ & $\begin{array}{l}\text { - bottom up program } \\
\text { - inisiasi komunitas } \\
\text { dan jaringan }\end{array}$ & $\begin{array}{l}\text { - dana berasal dari } \\
\text { swadaya (tabungan) } \\
\text { dan bantuan seed } \\
\text { program jaringan }\end{array}$ & $\begin{array}{l}\text { - partisipasi mencakup } \\
\text { pemetaan, } \\
\text { perencanaan, dan } \\
\text { pemetaan }\end{array}$ \\
\hline
\end{tabular}

Sumber: Analisa, 2020

Jurnal PAWON, Nomor 02 Volume IV, Bulan Juli-Desember Tahun 2020, ISSN 2597-7636 
Inisiasi Paguyuban Kalijawi dan Arkom Yogya tidaklah terbentuk dengan instan. Sejak 2010, Arkom yang merupakan kelompok arsitektur komunitas bekerja untuk memperkuat komunitas permukiman informal di Yogyakarta. Sebagai bagian dari Asian Coalition for Community Action (ACCA) yang diinisiasi oleh Asian Coalition for Housing Right (ACHR), Arkom membantu komunitas masyarakat untuk bisa menemu kenali problem mereka dan mencari solusi bersama. Proses ini berkembang melalui serangkaian proses survey, pemetaan, tabungan bersama, perencanaan, dan workshop yang berupaya menunjukkan realitas bahwa masyarakat informal bukanlah masalah namun bisa bergerak membangun permukiman layak dengan kerjasama komunitas yang solid (ACHR, 2014). Adapun metode yang dilakukan Arkom dan Komunitas adalah melalui serangkaian tahapan partisipatif sebagai berikut Pemetaan Partisipatif, Perencanaan Partisipatif, dan Pelaksanaan Partisipatif.
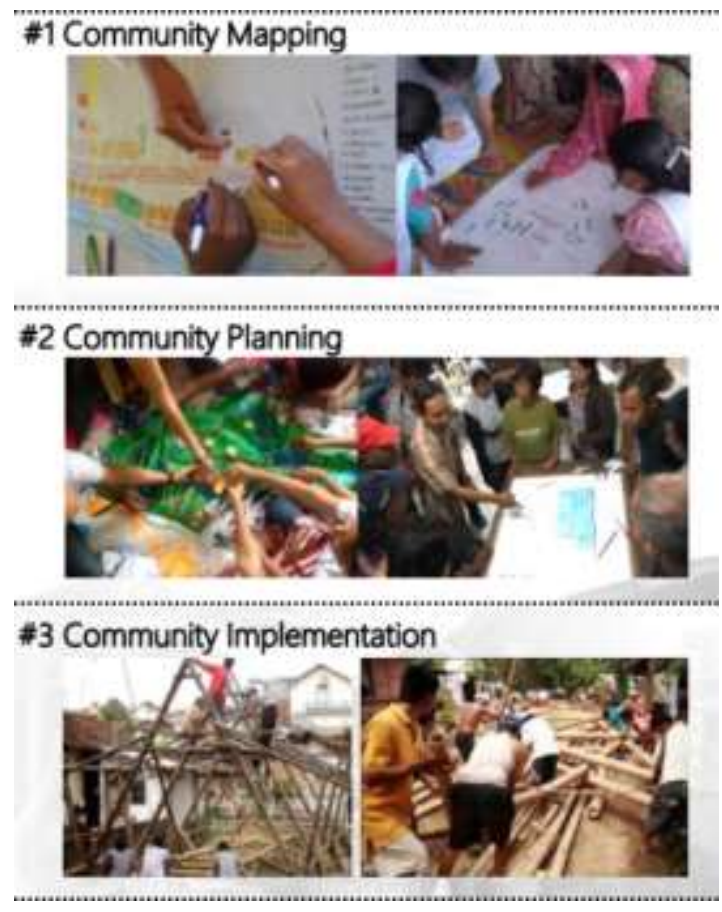

Gambar. 1

Metode Partisipatif Arkom

Sumber: Re-Pro Profil Arkom oleh Penulis, 2020

Inisiasi Kalijawi dan Arkom dimulai dengan pemetaan 13 permukiman dengan berbagai kondisi. Awal mulanya proses survey dan pemetaan 
dimaksudkan untuk menghubungkan komunitas yang rentan dengan jaringan lintas komunitas dan membangun koalisi yang kuat untuk melakukan proses advokasi dengan pemerintah lokal. Inisiasi ini berupaya mempromosikan model pembangunan berbasis komunitas untuk berkontribusi dalam menyelesaikan permasalahan permukiman kumuh di kota. Pemetaan komunitas dilakukan oleh warga sendiri dangan pendampingan dari Arkom. Pemetaan komunitas ini nantinya akan dikoneksikan pada tingkatan skala yang lebih tinggi yakni skala kota agar komunitas-komunitas ini saling terhubung dan membangun pengetahuan bersama. Paguyuban Kalijawi sendiri memiliki beberapa pertemuan reguler yang terbagi pada beberapa tingkat:

Tabel 2.

Jenis Pertemuan Kalijawi

\begin{tabular}{|c|c|}
\hline Jenis Pertemuan & Peserta \\
\hline Pertemuan Kelompok Kecil & Kelompok Paguyuban \\
\hline Pertemuan Kelompok Besar & Perwakilan Kelompok Paguyuban \\
\hline Pertemuan Komunitas & Paguyuban dan Arkom \\
\hline Pertemuan Jaringan & Paguyuban-Paguyuban dan Arkom \\
\hline Pertemuan Lintas Jaringan & $\begin{array}{c}\text { ACCA, ACHR, Arkom, Kalijawi, SDI, } \\
\text { Universitas, Pemerintah }\end{array}$ \\
\hline
\end{tabular}

Sumber: Analisa, 2020

Pendekatan seperti ini dapat membuat komunitas informal lebih terlihat dan mampu berjejaring dnegan kuat. Jaringan terbentuk melalui serangkaian dialog dan diskusi antar komunitas sehingga terbentuklah komunitas masyarakat yang aktif. Pemetaan bersama secara perlahan memberikan pengetahuan tentang kesadaran kondisi permukiman mereka untuk kemudian dikembangkan menjadi proyeksi perencanaan masa depan. Melalui dana grant inisiasi dari ACCA perencanaanpun juga bisa dilanjutkan pada proses pelaksanaan bahkan dikembangkan melalui mekanisme tabungan bersama dan arisan. Hal ini tidak hanya memperkuat aspek ekonomi, namun secara bersamaan meningkatkan ikatan sosial dan daya tawar politis komunitas ini.

Sementara itu jaringan-jaringan yang terbentuk baik dari komunitas, perguruan tinggi, profesional, serta lembaga swadaya masyarakat lainnya mampu memberikan dampak yang signifikan terutama terkait pembentukan pengetahuan, penguatan kapasitas sampai pembiayaan. Apalagi jaringanjaringan ini secara reguler bertemu sehingga bisa didapatkan solusi dan saran dari banyak pihak juga dijadikan sebagai media belajar bersama mengenai program dan kegiatan pada skala, kondisi, dan karakteristik yang berbeda. 
Secara mendetail pertemuan lintas jaeingan ini dimulai dari pertemuan kecil antar kelompok, kemudian dibawa pada pertemuan pada skala kota. Arkom sendiri membawa isu-isu dan hal-hal yang bisa dijadikan pembelajaran melalui jaringan dan pertemuan internasional. Sebagai bagian dari ACCA, CAN, dan ACHR mereka juga aktif bertemu setidaknya setahun sekali untuk berbagi pengalaman berbeda mengenai proses pendampingan komunitas di banyak negara berbeda di Asia.

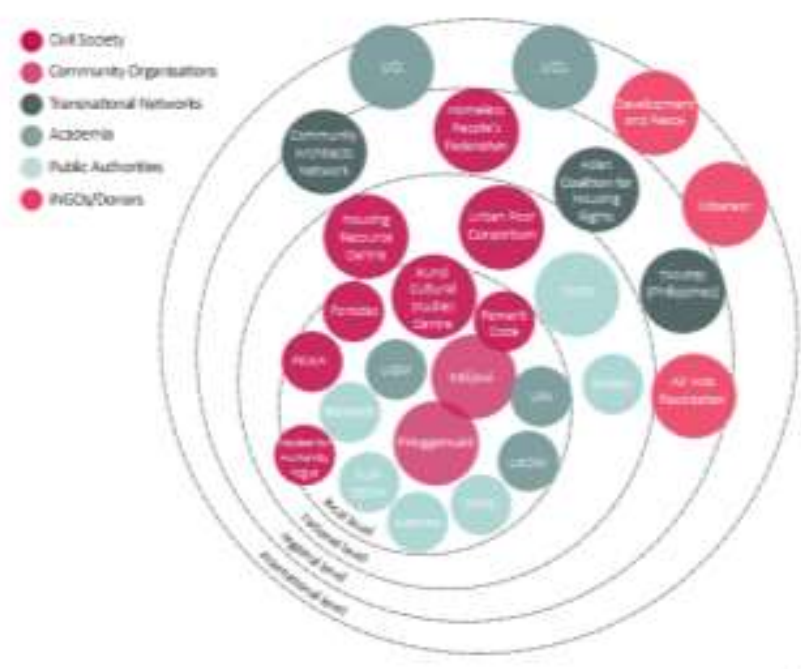

Gambar. 2

Jaringan Lintas Arkom dan Paguyuban

Sumber: Grounded Learning, 2020

\section{KESIMPULAN}

Pembangunan partisipatif berkelanjutan semestinya tidak hanya berhenti pada kontribusi masyarakat dan komunitas dalam persetujuan proyek belaka. Tetapi menuju pembangunan berkelanjutan masyarakat dan komunitas harus ditempatkan sebagai subyek pembangunan. Dua kasus telah didiskusikan dengan perspektif partisipasi yang berbeda. KIP hadir sebagai perpanjangan tangan program pemerintah di masa awal desentralisasi. Sedang inisiasi Paguyuban Kalijawi menunjukkan bagaimana desentralisasi seharusnya memberi ruang kontribusi masyarakat dan komunitas dalam pembangunan. Karena itu perkuatan aspek sosial, ekonomi, dan politis dalam melakukan proses pembangunan partisipatif menjadi sangat penting untuk dipertimbangkan. Selain itu koneksi melalui jejaring antar komunitas juga memberikan dampak dan solusi yang lebih baik bagi komunitas dan masyarakat. 
Pada konteks Indonesia, gotong royong merupakan aset yang sangat kritikal dan mendasar untuk menginisiasi proses pembangunan partisipatif. Kondisi eksisting ini dan dengan berjalannya proses desentralisasi harusnya menjadi peluang perbaikan lingkungan yang bisa berjalan berkelanjutan. Pemahaman tentang konteks dan karakter lokal juga menjadi titik tolak yang baik untuk mengenali alternatif kemungkinan, potensi, kendala dalam proses berlangsungnya pembangunan.

Lebih lanjut, jaringan lintas komunitas akan menjawab bagaimana kita memahami ruang, kuasa, dan pengetahuan sangat berperan dalam proses transformasi pembangunan. Keterjalinan antar komunitas melalui proses diskusi, dialog, dan pembentukan pengetahuan bersama akan membuat proses partisipatif menjadi lebih berdampak nantinya. Koneksi antar komunitas ini tidak hanya menunjukkan proses pembangunan yang telah dilakukan tetapi juga memberikan bukti nyata implementasi gotong royong dalam mengatasi permasalahan-permasalahan lingkungan.

\section{DAFTAR PUSTAKA}

ACHR. (2010). Community architects in Asia - design with by for people. Asian Coalition For Housing Right. Bangkok: ACHR.

ACHR. (2014). ACCA Fifth Year Report. Thailand: ASian Coalition for Housing Rights.

Boano, C., \& Kelling, E. (2013). Towards an Architecture of Dissensus: Participatory Urbanism in South-East Asia. The Participatory Turn in Urbanism , 41-62.

Butcher, H. (1993). Intoductuon: Some Examples and Definitions. In H. Butcher, A. Glen, P. Henderson, \& J. Smith (Eds.), Community and Public Policy (pp. 321). London: Pluto Press.

Das, A. (2015). Participatory Slum Upgrading: Lessons from Post-Decentralization India and Indonesia. Journal of Indonesian Regional Development and Environment, 1, 15-34.

Das, A. K. (2009). What's real and what's rhetorical? The effects of decentralization. Annual Conference of the Association of Collegiate Schools of Planning. Chicago.

Day, P. (2002). Designing Democratic Community Networks: Involving Communities through Civil Participation. In M. Tanabe, V. Besselaar, \& T. Ishida (Eds.), Digital Cities (pp. 86-100). Berlin: Springer-Verlag.

Fitrianto, A. (2014). Securing local ownership, and the architect's dilemma. $(H$. Moksnes, \& M. Melln, Eds.) Claiming the City: Civil Society Mobilisation by the Urban Poor, 95-104.

Iqbal, M. (2018). Advancing Social Capital through Participatory Approaches Case of Community-Based Slum Upgrading in Yogyakarta, Indonesia. EMARA Indonesian Journal of Architecture, 1-13. 
Kouri, Marina, Hofer, K., Sallam, N., \& Amalsyah, A. (2020). Grounded Learning: People-Centred Approaches to Housing in Yangon and Yogyakarta. London: DPU-UCL.

Ley, A. (2018). Translocal networking as a cornerstone for community resilience: ctivities by the Asian Coalition of Housing Rights. International Forum on Urbanism . Barcelona: IFoU.

Mayo, Marjorie; Craig, David;. (1995). Community Empowerment a reader in participation and development. (M. Mayo, \& D. Craig, Eds.) New York: Zed Books Ltd.

Mintorogo, D. S., Arifin, L., Widigdo, W., \& Juniwati, A. (2015). Historical Old "Kampung" Toward Sustainable Green and Clean Habitat. International Joint Conference of SENVAR-iNTA-AVAN 2015. Johar: UTM Malaysia.

Mitlin, D., \& Satterthwaite, David. (2012). Addressing Poverty and Inequality: New Forms of Urban Govenance in Asia. Environment and Urbanization, 24(2), 395-401.

Nasution, A. (2016, October 2016). Government Decentralization Program in Indonesia. Retrieved May 25, 2020, from https://www.adb.org: https://www.adb.org/publications/government-decentralization-programindonesia

Purba, R. E. (2011). Public Participation in Development Planning: A Case Study of Indonesian Musrenbang. nternational Journal of Interdisciplinary Social Sciences, 13.

Setiawan, A. (2017). Produksi Ruang Sosial sebagai Konsep Pengembangan Ruang Perkotaan (Kajian atas Teori Ruang Henry Lefebvre). Haluan SAstra Budaya, 1-12.

Sindre, G. M. (2012). Civic Engagement and Democracy in Post-Suharto Indonesia: A Review of Musrenbang, the Kecamatan Development Programme, and Labour Organising. Power Conflict Democracy, 1-40.

Sugiyono. (2017). Metode Penelitian Kualitatif. Bandung: Alfabeta.

Widiyanto, D. (2014, April 21). Retrieved December 08, 2015, from www.krjogja.com: http://krjogja.com/read/213093/warga-winongo-berharappenataan-sungai-berbasis-masyarakat.kr 